\title{
SACRIFICES FOR STATE AND NATION
}

\section{By Gov. Albert B. Cummins}

I do not remember an hour of deeper interest or of greater earnestness than that through which we are now passing. The occasion is deeply interesting; it is highly instructive, no matter what point of view may be assumed. It must be very gratifying to the people of this county, to the citizens of this community, to recall or have recalled in their hearing, in the eloquent phrases to which we have just listened, the memory of so estimable a man, so great a leader, and so efficient a worker for humanity. It must be a source of pride to those who remember this distinguished citizen of Iowa, to again hear recited his worthy deeds, not only that they may love his memory more, but that they may be stimulated to follow his excellent example.

I rejoice with you in the possession of such a citizen; I rejoice with you that through his labors so noble an institution was established and has been maintained in your midst; but to me the moment is especially significant in that it recalls something of the wonderful advance that humanity has made during the last few years -I call them few, and they are few in comparison with all that have rolled across the stream of time. I think of this occasion as one fit to recall what has been done in the past to better the state, the men and women, and the boys and girls who live in it. It isn't all done yet. There is a great field yet to be occupied-a great many heights that are yet to be attained, but it has become possible in looking into the future to ascertain what is yet to be done, to view the magnificent work, the unselfish labor with which the annals of time are marked and inscribed.

As I recall, the state of Iowa, the people of the state of Iowa, now contribute every year about twenty-three millions of dollars in taxes, and it must make every heart throb with a little pride-every face kindle with a little more gratification-to remember that more than 
half of all the money which the people of this state contribute is for educational purposes, and I now embrace every form of education-more than half of all they now contribute is devoted to the cause of education. Twelve or more millions of dollars are expended every year in order to fit the growing generation for the duties of citizenship.

When I rank Iowa-when I see the station that Iowa occupies in relation to the other states of our republicmy heart is still further filled with pride. We are not only among the first of the states to develop, not the charity but the sense of duty which is here carried out. And Iowa has performed that duty more efficiently probably, all things considered, than any other state in the Union. I do not think there is in any other state a school for the blind that has taken higher rank in the fields of learning than the institution that has been established and carried on in your midst.

I know there is a general misapprehension. I wish that every man in the state of Iowa could know what has been done. It is simply doing for those unfortunate blind what it is doing for other boys and girls in other schools. I hope the work may be extended so that the graduates as they go from the institution from year to year may become more successful in the great study of life. We can't have too much pride in our state and our country when we look back and see what has been done.

I see before me many men wearing that veteran's badge. I am glad that they come to testify of their in... terest not only in their old comrade, but in the wori: that is here being carried on.

\section{COUld They But KNow!}

I spent two days last week going over the battlefield of Shiloh. There something like 4,000 of our boys are resting in a beautiful cemetery, shaded with magnificent oaks, and lulled, if they needed lulling, into everlasting: sleep, - that silent, death sleep, by the murmurs of the Tennessee river. And, as I stood there, the thought 
which impressed itself upon my mind most deeply was this: I wonder if these boys know what a country they fought for, and what a flag they saved. I wonder if their eyes now can see the glory of the Republic. I wonder if they understand these sublime attitudes to which our Republic has at last attained; and I wonder whether you old comrades can think how far we have gone along since 1860, and understand how we have carried along the idea so impressed by Thomas Drummond. It is a gratification to believe that these men who would wear that little badge, if they had not been called to the other shore, that they know what their state and their country is doing for humanity, and how it is using the priceless victories for which they laid down their lives.

There is no thought that can stimulate higher citizenship than the thought of duty. They gave all that men have to give for their country, and it is for us in times of peace to follow their patriotism, because it is just as difficult to be a patriot in the time of peace as it is to be a patriot in time of war. Peace has its duties and its responsibilities, not less important, nor less charged with the importance of our country, than the duties of war and I am glad we have gathered together this summer afternoon, with the light of peace all about us, with nothing to disturb the serenity of the heart and nothing to alarm the mind.

\section{THE PATH OF DUTY}

We are here to rejoice that our country and our state have done so much for humanity. We are here to make an entry upon the journal of time, an entry of appreciation and of love and affection. It will do him no good -he has passed beyond-but it will do us good. Because of this occasion we can take on a better resolve concerning our own duty. We can determine with an intensity never before felt, that no matter what may be the influences that draw us away from the path of duty, yet we will walk in it.

And so these occasions will not only commemorate the memory of men who have gone to the other shore, will 
not only express our appreciation of what they have done, but will make us a little more able and more willing to follow in their footsteps. I count it a great privilege to be here and to say these few words to you. They are unprepared and they have but one merit and that is, they spring from a heart that is in utter and absolute sympathy with the spirit of the hour.

Mr. Sells, it gives me great pleasure to say that on behalf of the state of Iowa, I accept this beautiful and impressive tablet and to express the confident belief that it will be permanently placed in a prominent position in this building and that so long as this structure shall stand, so long shall the students of the institution and the passing multitude know and appreciate the virtues and merit of your distinguished citizen.

\section{PROSPERITY, STABILITY AND HAPPINESS}

Gov. Stephen Hempstead: With a soil of great richness and productiveness, a climate salubrious and invigorating, and citizens possessing enterprise and industry, we require nothing more than what is secured in the constitution; and let me say, if we desire a continuance of that prosperity, the stability of the state and the happiness of our citizens, it can only be accomplished by the enactment of equal and expedient laws, and not by those which are designed to build up and enrich the few at the expense of the many, or by giving one class of citizens privileges not possessed by others.

The leading principles of a republican government, as I understand them, are "a perfect equality of political rights, a strict construction of constitutions, no monopolies, moderate legislation, a revenue meeting the wants of the people, and no more; strict responsibility of public officers, simplicity of the laws, and the least possible restraint upon the mind, person, energy and industry of every man, consistent with the rights of his fellow men." -Inaugural address to the Third General Assembly of Iowa, December 4, 1850. 
Copyright of Annals of Iowa is the property of State of Iowa, by \& through the State Historical Society of Iowa and its content may not be copied or emailed to multiple sites or posted to a listserv without the copyright holder's express written permission. However, users may print, download, or email articles for individual use. 